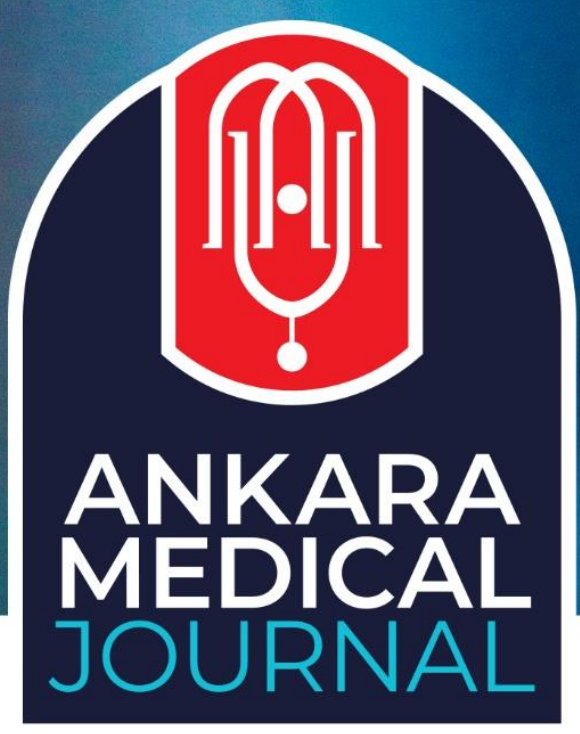

Research Article

Ankara Med J, 2020;(1):153-169 // 10 10.5505/amj.2020.82653

\title{
ATTITUDES TOWARDS SUN PROTECTION AND SKIN CANCER AMONG FACULTY MEMBERS AND STUDENTS OF MEDICINE AND OF ARTS/SCIENCES AT A TURKISH UNIVERSITY
}

BİR TÜRK ÜNIVERSITTESINNEKII TIP VE FEN-EDEBIYYAT FAKÜLTELERİ ÖĞRETIM ÜYELERİ VE ÖĞRENCILERINIIN GÜNEŞTEN KORUNMA VE CİLT KANSERİNE KARŞI TUTUMLARI

(D) Coşkun Öztekin1, (D) Aynure Öztekin², (D) Engin Senel ${ }^{2}$ ${ }^{1}$ Hitit University, School of Medicine, Department of Family Medicine, Çorum ${ }^{2}$ Hitit University, School of Medicine, Department of Dermatology, Çorum

Yazışma Adresi / Correspondence:

Coşkun Öztekin (e-mail: coskunoztekin@gmail.com)

Geliş Tarihi (Submitted): 24.07.2019 // Kabul Tarihi (Accepted): 10.01.2020

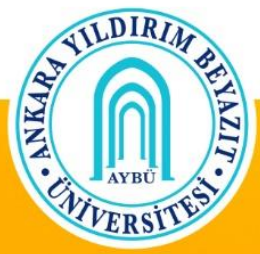

Ankara Yıldırım Beyazit University Faculty of Medicine Department of Family Medicine 


\title{
Öz
}

Amaç: Güneşten korunma uygulamaları hakkında halkın bilgisi ve tutumu, cilt kanserinden ve güneșe maruz kalmanın diğer zararlı etkilerinden korunmada önemli faktörlerdir. Topluma tıbbi bilgi vermeleri ve halk sağlı̆̆ı politikalarını şekillendirmeleri sebebiyle tıp öğrencilerinin ya da eğitimcilerin farkındalık seviyeleri de önemlidir. Bu çalışmanın amacı, bir Türk üniversitesindeki tıp ve fen-edebiyat fakülteleri öğretim üyeleri ve öğrencilerinin güneș ışığına maruz kalmanın ve güneșten korunmanın etkilerine yönelik bilgi ve tutumlarını ortaya koymaktır.

Materyal ve Metot: $\mathrm{Bu}$ tanımlayıcı enine kesitsel çalışma, Hitit Üniversitesi Fen Edebiyat Fakültesi, Tıp Fakültesi ve Sağlık Hizmetleri Meslek Yüksekokulu öğrencilerine ve öğretim üyelerine 37 maddelik bir anket uygulayarak gerçekleştirildi. Sorular, katılımcıların güneşe maruz kalma ve güneşten korumanın etkileriyle ilgili bilgi düzeylerini, bu konularla ilgili bilgi kaynaklarını ve çevresel faktörlerle ilgili davranışlarını değerlendirmeye yönelik olarak formüle edildi. Yanıtlar uygun araç ve yöntemlerle istatistiksel analizlere tabi tutuldu.

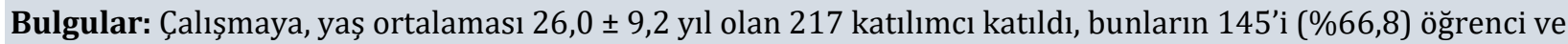
72'si (\%33,2) öğretim üyesiydi. Katılımcıların 118'i (\%55,1) kadın, 151'i $(\% 69,6)$ tıp alanındaydı. Katılımcıların büyük çoğunluğu ( $n=204, \% 94)$ güneş kremi kullanıyordu ve en sık olarak SPF> 30 olan güneş kremi kullanılmaktaydı (\%44). Güneșten koruyucu alırken marka $(\% 45,2)$ ve yüksek SPF $(\% 46,2)$ en çok göz önünde bulundurulan faktörlerdi. Katılımcıların cinsiyet, unvan ve çalışma alanına göre karşılaștırılması, güneş ışığına maruz kalma ve güneșten korunma ile ilgili bilgi ve uygulamalarda gruplar arası bazı farklılıklar olduğunu göstermiștir.

Sonuç: Tıbbi alandaki öğrenciler ve öğretim üyeleri, tıbbi olmayan alanlardan olanlara kıyasla güneşe maruz kalma ve güneșten korunma ile ilgili konularda genel olarak daha yüksek bilgi düzeyine sahip olsalar da, tıp öğrencileri ve öğretim üyeleri arasında bile güneșe maruz kalma ile ilişkili risklerin ciddiyeti hakkında hala önemli bir bilgi eksikliği bulunmaktadır. Halkın bilinçlendirilmesinde kullanılan yöntemler ve medya kanalları, hedef kitlelerin demografik özelliklerine göre uyarlanmalıdır. Bu çalışmanın hedef popülasyonundaki genel tabloyu ortaya koyabilmek için, daha kapsamlı ve organize veri toplama araçları ve daha çeşitli kurumlardan geniş bir örneklemle yapılacak çalışmalara ihtiyaç vardır.

Anahtar Kelimeler: Cilt kanseri, güneșten korunma, güneş kremi kullanımı, halk sağlı̆̆ı, davranış, bilgi.

\begin{abstract}
Objectives: Public knowledge about and attitude towards sun protection practices are important factors in attempts to avoid skin cancer and other harmful effects of sun exposure. Such are the awareness levels of the students of medicine or their educators as they deliver the information to the general public and shape public health policies. The aim of this study was to reveal the knowledge and attitudes of the faculty members and students of medicine and of arts/sciences at a Turkish university towards the effects of sun exposure and protection.
\end{abstract}

Materials and Methods: This descriptive cross-sectional study was conducted by administering a 37-item questionnaire to students and faculty members in the School of Arts/Sciences, School of Medicine, and Vocational School of Medical Sciences at Hitit University. The questions were formulated to evaluate the participants' level of knowledge regarding the effects of sun exposure and protection, the source of their knowledge about these subjects, and their behaviors related to environmental factors. Responses were subjected to statistical analyses with appropriate tools and methods.

Results: The study included a total of 217 participants with an average age of $26.0 \pm 9.2$ years: 145 (66.8\%) students and 72 (33.2\%) faculty members. Of these, 118 (55.1\%) were female and $151(69.6 \%)$ were in medical fields. A great majority of the participants $(n=204,94 \%)$ had used sunscreens, and sunscreens with $\mathrm{SPF}>30$ were the most commonly used ones (\%44). Brand (45.2\%) and high SPF (46.2\%) were the most frequently considered aspects when buying sunscreens. A comparison of subgroups of participants based on gender, position, and area of study indicated some differences in knowledge and practices related to sun exposure and sun protection. 
Conclusion: Although students and faculty members of medical areas had generally higher level of knowledge about the issues surrounding sun exposure and protection in comparison with those from non-medical backgrounds, there is still a significant knowledge deficit about the severity of associated risks and some room for improvement even among the students and faculty members of medical schools. The methods and media channels that would be used to increase public awareness should be adapted according to the demographic characteristics of target audiences. Further studies with a more comprehensive and well-managed data collection tools and a larger sample from more diverse set of institutions are warranted to determine the overall picture in the target population of this study.

Keywords: Skin cancer, sun protection, sunscreen use, public health, behavior, knowledge. 


\section{Introduction}

Skin cancers (more aggressive melanomas and less aggressive non-melanomas), one of the most common types of cancers worldwide, are a growing but preventable public health problem. ${ }^{1,2}$ Depletion of stratospheric ozone layer, which absorbs as much as 99.9\% and 95\% of ultraviolet (UV)-B and -A lights (280-320 and 320-400 nm), has led to an increase in global ground-level UV irradiation in the last decades 3,4 and corresponding significant increases in the incidence of, in the number of treatments for, or in deaths due to skin cancers. ${ }^{1,5,6}$ Exposure to sunlight, which is valued as an important means to generate vitamin D, also carries a greater risk for DNA damage and mutations. ${ }^{7}$ Studies indicate that over $75-90 \%$ of skin cancers are considered to result from excessive exposure to outdoor or indoor UV radiation through sunlight or tanning beds. ${ }^{8,9}$ Accordingly, UV radiation is considered a significant preventable environmental risk factor for all types of skin cancers. 9,10

Sunscreens of different strengths (sun protection factor - SPF) are applied onto the skin in order to limit the exposure of skin cells to UV light. However, the method and amount of sunscreen applied have been shown to vary among individuals significantly and to have a negative impact on the actual level of protection. ${ }^{11,12}$ Moreover, public knowledge about and attitude towards UV protection practices are also important factors in attempts to protect the public from skin cancer and other harmful effects of UV exposure. ${ }^{13,14}$ Public education programs are commonly implemented to educate the public and to promote appropriate UV protection practices. ${ }^{15,16}$ On the other hand, the level of awareness among the students of medicine or their educators about UV protection practices is a subject of greater interest since they would be the ones delivering the information about this subject to the general public and shaping the public health policies. The aim of this study was to reveal the knowledge and attitudes of the faculty members and students of medicine and of arts/sciences at a Turkish university towards the effects of sun exposure, sun protection, and skin cancer in order to guide future educational programs and public health policies.

\section{Materials and Methods}

This descriptive cross-sectional study was conducted between October-December 2018 at Hitit University in Turkey. The university has over 14,000 students enrolled in undergraduate programs and accepts students in the mid-range for respective programs in terms of the nationwide entrance exam results. The participants were informed about the objectives and the procedures of the study, were given assurances of anonymity, and were asked to give their written approval. The local ethics committee for non-interventional studies at Hitit University approved this study (Approval \#2018-77, Date 05.04.2018). The study protocol conforms to the ethical guidelines of the 1975 Declaration of Helsinki as reflected in the approval by the institution's human research committee. 
A 37-item anonymous questionnaire adapted from Şenel and Süslü13,17 was administered to faculty members and undergraduate students in the School of Arts/Sciences, School of Medicine, and Vocational School of Medical Sciences at Hitit University. The questions were formulated to evaluate participants' level of knowledge regarding the effects of sun exposure and protection, their behaviors related to environmental factors, and the source of their knowledge about these subjects. The questionnaire contained 26 statements presented to the participants as 5-point Likert-type items (S11, S18-S37, 'Strongly agree', 'Agree', 'Not sure', 'Disagree', 'Strongly disagree') along with yes/no questions and those inquiring about their socioeconomic background. The statements roughly covered the subjects related to the use and knowledge of solarium (S11ab, S30, S33, and S37), tanning (S32, S34, and S35), harmful effects of sun rays (S23, S24, S25, and S26), risk factors for skin cancer (S27, S28abcde, S29, and S36), protective measures in summer (S18, S19, S20, and S21), and sunscreen use (S22 and S31). Some of these statements were true to the scientific knowledge (S11b, S19, S20, S21, S22, S23, S24, S26, S27, S28abcde, S29, S35) while others were false (S11a, S18, S25, S30, S31, S32, S33, S34, S36, S37).

Statistical analyses were performed with SPSS (Version 22.0, SPSS Inc., Chicago, IL, USA). The normal distribution was examined by the Kolmogorov-Smirnov test. Descriptive statistics were presented as number and percentage for the demographic and other categorical variables and as mean \pm standard deviation or median (min-max) for continuous variables. Independent-samples t-test or analysis of variance (ANOVA) was used for the comparison of two or multiple groups regarding the continuous variables with normal distribution, respectively. Mann-Whitney $U$ test was used for the comparison of two groups regarding the data without normal distribution (i.e., responses to the statements given in the questionnaire). Relationships were analyzed with Spearman's correlation coefficient between numerical variables or chi-square test for categorical variables. Results with $p<0.05$ were considered statistically significant.

\section{Results}

A total of 217 participants were included in the study: 145 (66.82\%) students and 72 (33.18\%) faculty members. Of these, 118 (55.14\%) were female, 151 (69.58\%) were in medical fields (medical school or vocational school of health), and 139 (64.65\%) had medium to dark skin tones (Table 1). The average age of participants was $26.02 \pm 9.18$ years. The great majority of the participants $(n=208,95.85 \%)$ did not have a close relative who had had skin cancer; none had skin cancer in the family.

Most of the participants $(\mathrm{n}=117,53.92 \%)$ had 1-4 hours of daily sun exposure during summer and (n=140, $64.52 \%$ ) had sunburn (Table 2). A great majority of the participants ( $n=204,94.01 \%)$ had used sunscreens, and sunscreens with SPF $>30$ were the most commonly used ones (\%44.61). No significant relationship was found between having sunburn and not using sunscreen (Fisher's exact test $p=0.775$ ). 
Table 1. Demographic data of the students and faculty members.

\begin{tabular}{|c|c|c|}
\hline Groups $(\mathrm{N}=217)$ & $\mathbf{n}$ & $\%$ \\
\hline Student & 145 & 66.82 \\
\hline School of Arts \& Sciences & 59 & 27.19 \\
\hline Vocational School of Health & 28 & 12.90 \\
\hline Medical School & 58 & 26.73 \\
\hline Faculty Member & 72 & 33.18 \\
\hline Medical School & 65 & 29.95 \\
\hline Arts \& Sciences & 7 & 3.23 \\
\hline Gender $(\mathrm{N}=214)$ & $\mathbf{n}$ & $\%$ \\
\hline Male/Female & $96 / 118$ & $44.86 / 55.14$ \\
\hline Students $(\mathrm{M} / \mathrm{F})$ & $49 / 93$ & $34.51 / 65.49$ \\
\hline Faculty members (M/F) & $47 / 25$ & $65.28 / 34.72$ \\
\hline Age, years $(\mathrm{N}=214)($ Mean $\pm \mathrm{SD})$ & $26.02 \pm 9.18$ & \\
\hline Students $(n=144)$ & $20.35 \pm 1.77$ & \multirow{2}{*}{$p<0.001^{\mathrm{a}}$} \\
\hline Faculty members $(n=70)$ & $37.69 \pm 6.95$ & \\
\hline Skin Tones $(\mathrm{N}=215)$ & $\mathbf{n}$ & $\%$ \\
\hline Fair & 11 & 5.12 \\
\hline Light & 65 & 30.23 \\
\hline Medium & 79 & 36.74 \\
\hline Dark & 60 & 27.91 \\
\hline Eye Color $(\mathrm{N}=213)$ & $\mathbf{n}$ & $\%$ \\
\hline Hazel & 37 & 17.37 \\
\hline Brown & 148 & 69.48 \\
\hline Green & 12 & 5.63 \\
\hline Black & 8 & 3.76 \\
\hline Blue & 7 & 3.29 \\
\hline Amber & 1 & 0.47 \\
\hline Hair Color $(\mathrm{N}=209)$ & $\mathbf{n}$ & $\%$ \\
\hline Blonde & 11 & 5.26 \\
\hline Light brown & 39 & 18.66 \\
\hline Black & 82 & 39.23 \\
\hline Dark brown & 63 & 30.14 \\
\hline Chestnut brown & 6 & 2.87 \\
\hline Red & 2 & 0.96 \\
\hline Gray & 5 & 2.39 \\
\hline White & 1 & 0.48 \\
\hline Family history of skin cancer $(\mathrm{N}=217)$ & $\mathbf{n}$ & $\%$ \\
\hline No & 208 & 95.85 \\
\hline Yes - Degree of kinship & 9 & 4.15 \\
\hline Not specified & 2 & 22.22 \\
\hline Grandparent & 3 & 33.33 \\
\hline Aunt/Uncle & 2 & 22.22 \\
\hline Cousin & 2 & 22.22 \\
\hline
\end{tabular}

SD: Standard deviation

andependent samples t-test. 
Table 2. Participants' behavior regarding sun exposure and sunscreen use.

\begin{tabular}{|c|c|c|}
\hline Daily sun exposure during summer $(\mathrm{N}=217)$ & $\mathbf{n}$ & $\%$ \\
\hline Not at all & 17 & 7.83 \\
\hline$<1 \mathrm{hr}$ & 44 & 20.28 \\
\hline $1-4 \mathrm{hrs}$ & 117 & 53.92 \\
\hline 5-9 hrs & 39 & 17.97 \\
\hline History of sunburn $(\mathrm{N}=217)$ & $\mathbf{n}$ & $\%$ \\
\hline No & 77 & 35.48 \\
\hline Yes & 140 & 64.52 \\
\hline Sunscreen use $(\mathrm{N}=217)$ & $\mathbf{n}$ & $\%$ \\
\hline No & 13 & 5.99 \\
\hline Yes - SPF used & 204 & 94.01 \\
\hline Not known & 69 & 33.82 \\
\hline$<$ SPF 15 & 7 & 3.43 \\
\hline SPF $16-29$ & 37 & 18.14 \\
\hline$>$ SPF 30 & 91 & 44.61 \\
\hline Sunscreen-applied body parts daily $(\mathrm{N}=217)$ & $\mathbf{n}$ & $\%$ \\
\hline None & 84 & 38.71 \\
\hline Face & 114 & 52.53 \\
\hline Upper extremities & 15 & 6.91 \\
\hline Lower extremities & - & - \\
\hline Trunk & 4 & 1.84 \\
\hline Sunscreen-applied body parts at beach $(\mathrm{N}=217)$ & $\mathbf{n}$ & $\%$ \\
\hline Face & 174 & 80.18 \\
\hline Upper extremities & 155 & 71.43 \\
\hline Lower extremities & 104 & 47.93 \\
\hline \multirow[t]{2}{*}{ Trunk } & 124 & 57.14 \\
\hline & Mean & \pm SD \\
\hline Age at first sunscreen use $(\mathrm{N}=155)$ & 16.61 & \pm 7.86 \\
\hline Sunscreen buying criteria $\left(1^{\text {st }}\right)(\mathrm{N}=208)$ & $\mathbf{n}$ & $\%$ \\
\hline Brand & 94 & 45.19 \\
\hline Price & 14 & 6.73 \\
\hline High SPF & 96 & 46.15 \\
\hline Other & 4 & 1.92 \\
\hline Sunscreen buying criteria $\left(2^{\text {nd }}\right)(\mathrm{N}=76)$ & $\mathbf{n}$ & $\%$ \\
\hline Brand & 1 & 1.32 \\
\hline Price & 21 & 27.63 \\
\hline High SPF & 45 & 59.21 \\
\hline Perfume & 2 & 2.63 \\
\hline Unscented & 7 & 9.21 \\
\hline Sunscreen application time $(\mathrm{N}=206)$ & $\mathbf{n}$ & $\%$ \\
\hline $1 \mathrm{hr}$ before exposure & 26 & 12.62 \\
\hline Half hr before exposure & 135 & 65.53 \\
\hline During sun exposure & 35 & 16.99 \\
\hline After sun exposure & 1 & 0.49 \\
\hline Other & 9 & 4.37 \\
\hline
\end{tabular}

SD: standard deviation, SPF: sun protection factor 
Table 3. Participants' source of information and opinion regarding sun protection and UV light.

\begin{tabular}{|l|c|c|}
\hline $\begin{array}{l}\text { Most common source of information about the harmful effects of the sun } \\
(\mathrm{N}=207)\end{array}$ & $\mathbf{n}$ & $\mathbf{\%}$ \\
\hline Television & 53 & 25.60 \\
\hline Internet & 108 & 52.17 \\
\hline School & 19 & 9.18 \\
\hline Family & 8 & 3.86 \\
\hline Friends & 5 & 2.42 \\
\hline Newspapers & 1 & 0.48 \\
\hline Other & 13 & 6.28 \\
\hline $\begin{array}{l}\text { Knows that the UV light is responsible for the harmful effects of the sun } \\
\text { (N=195) }\end{array}$ & $\mathbf{n}$ & $\mathbf{\%}$ \\
\hline No & 5 & 2.56 \\
\hline Yes & 190 & 97.44 \\
\hline Do you find it necessary to protect from the sun? (N=217) & $\mathbf{n}$ & $\mathbf{\%}$ \\
\hline No & 24 & 11.06 \\
\hline Yes & 193 & 88.94 \\
\hline
\end{tabular}

UV: ultraviolet

Table 4. Comparison of behaviors of various subgroups of participants regarding sun exposure, sun protection, sunscreen use, etc.

\begin{tabular}{|c|c|c|c|}
\hline Subgroups compared & $\mathbf{N}$ & Compared response & $p$-value \\
\hline \multirow{6}{*}{$\begin{array}{l}\text { Gender } \\
\text { Male vs. Female }\end{array}$} & 214 & Daily sun exposure during summer & $0.113^{\mathrm{a}}$ \\
\hline & 214 & Sunscreen use & $\mathbf{0 . 0 1 4} 4^{\mathrm{b}}$ \\
\hline & 203 & Used sunscreen SPF & $\mathbf{0 . 0 0 1}^{\mathrm{b}}$ \\
\hline & 214 & Having sunburn & $0.045^{b}$ \\
\hline & 205 & Sunscreen buying criteria & $0.489^{a}$ \\
\hline & 205 & Source of information & $0.090^{\mathrm{a}}$ \\
\hline \multirow{6}{*}{$\begin{array}{l}\text { Position } \\
\text { Student vs. Faculty member }\end{array}$} & 217 & Daily sun exposure during summer & $<0.001^{\mathrm{a}}$ \\
\hline & 217 & Sunscreen use & $0.228^{b}$ \\
\hline & 204 & Used sunscreen SPF & $0.002^{b}$ \\
\hline & 217 & Having sunburn & $0.655^{b}$ \\
\hline & 208 & Sunscreen buying criteria & $0.006^{b}$ \\
\hline & 207 & Source of information & $<0.001^{\mathrm{a}}$ \\
\hline \multirow{6}{*}{$\begin{array}{l}\text { Area of study } \\
\text { Medical vs. non-Medical }\end{array}$} & 217 & Daily sun exposure during summer & $<0.001^{\mathrm{a}}$ \\
\hline & 217 & Sunscreen use & $0.222^{b}$ \\
\hline & 204 & Used sunscreen SPF & $0.156^{\mathrm{b}}$ \\
\hline & 217 & Having sunburn & $0.444^{b}$ \\
\hline & 208 & Sunscreen buying criteria & $0.261^{b}$ \\
\hline & 207 & Source of information & $0.031^{\mathrm{a}}$ \\
\hline
\end{tabular}

SPF, sun protection factor.

aPearson chi-square test.

bFisher's exact test. 
Table 5. Participants' opinions regarding sun exposure, sun protection, sunscreen use, and skin cancer.

\begin{tabular}{|c|c|c|c|c|c|c|c|c|c|c|c|}
\hline \multirow[b]{2}{*}{ Statement } & \multirow{2}{*}{$\mathbf{N}$} & \multicolumn{2}{|c|}{ S. agree } & \multicolumn{2}{|c|}{ Agree } & \multicolumn{2}{|c|}{ Not sure } & \multicolumn{2}{|c|}{ Disagree } & \multicolumn{2}{|c|}{ S. disagree } \\
\hline & & $\mathbf{n}$ & $\%$ & $\mathbf{n}$ & $\%$ & $\mathbf{n}$ & $\%$ & $\mathbf{n}$ & $\%$ & $\mathbf{n}$ & $\%$ \\
\hline $\begin{array}{l}\text { S11a. Solarium provides tanning without } \\
\text { being harmed. }\end{array}$ & 214 & 8 & 3.74 & 14 & 6.54 & 80 & 37.38 & 63 & 29.44 & 49 & 22.90 \\
\hline $\begin{array}{l}\text { S11b. Solarium may cause skin cancer in } \\
\text { the long term. }\end{array}$ & 213 & 57 & 26.76 & 77 & 36.15 & 74 & 34.74 & 5 & 2.35 & & \\
\hline $\begin{array}{l}\text { S18. It is appropriate to go to beach } \\
\text { between } 10 \text { AM - } 4 \text { PM during summer. }\end{array}$ & 212 & 17 & 8.02 & 54 & 25.47 & 17 & 8.02 & 75 & 35.38 & 49 & 23.11 \\
\hline $\begin{array}{l}\text { S19. It is appropriate to use sunglasses } \\
\text { during summer. }\end{array}$ & 215 & 102 & 47.44 & 94 & 43.72 & 10 & 4.65 & 8 & 3.72 & 1 & 0.47 \\
\hline $\begin{array}{l}\text { S20. It is appropriate to use hats during } \\
\text { summer. }\end{array}$ & 214 & 81 & 37.85 & 109 & 50.93 & 15 & 7.01 & 6 & 2.80 & 3 & 1.40 \\
\hline $\begin{array}{l}\text { S21. It is appropriate to use sunscreen } \\
\text { outside the beach. }\end{array}$ & 216 & 76 & 35.19 & 88 & 40.74 & 28 & 12.96 & 17 & 7.87 & 7 & 3.24 \\
\hline $\begin{array}{l}\text { S22. Sunscreens should be used in } \\
\text { children. }\end{array}$ & 215 & 85 & 39.53 & 75 & 34.88 & 40 & 18.60 & 8 & 3.72 & 7 & 3.26 \\
\hline S23. Sunrays have harmful effects. & 215 & 123 & 57.21 & 81 & 37.67 & 3 & 1.40 & 3 & 1.40 & 5 & 2.33 \\
\hline $\begin{array}{l}\text { S24. Sunrays may cause formation of } \\
\text { cataract in the eye. }\end{array}$ & 215 & 49 & 22.79 & 45 & 20.93 & 117 & 54.42 & 3 & 1.40 & 1 & 0.47 \\
\hline $\begin{array}{l}\text { S25. Sunrays may cause formation of } \\
\text { kidney stone. }\end{array}$ & 215 & 11 & 5.12 & 18 & 8.37 & 149 & 69.30 & 20 & 9.30 & 17 & 7.91 \\
\hline S26. Sunrays may cause skin cancer. & 215 & 97 & 45.12 & 87 & 40.47 & 27 & 12.56 & 4 & 1.86 & & \\
\hline $\begin{array}{l}\text { S27. Some drugs increase the sensitivity } \\
\text { to sunlight. }\end{array}$ & 214 & 71 & 33.18 & 87 & 40.65 & 54 & 25.23 & 2 & 0.93 & & \\
\hline $\begin{array}{l}\text { S28a. Light skin increases the risk of } \\
\text { developing skin cancer. }\end{array}$ & 210 & 73 & 34.76 & 62 & 29.52 & 58 & 27.62 & 13 & 6.19 & 4 & 1.90 \\
\hline $\begin{array}{l}\text { S28b. Presence of brown moles on the } \\
\text { body increases the risk of developing } \\
\text { skin cancer. }\end{array}$ & 208 & 61 & 29.33 & 72 & 34.62 & 65 & 31.25 & 7 & 3.37 & 3 & 1.44 \\
\hline $\begin{array}{l}\text { S28c. Sunburn increases the risk of } \\
\text { developing skin cancer. }\end{array}$ & 207 & 49 & 23.67 & 79 & 38.16 & 66 & 31.88 & 12 & 5.80 & 1 & 0.48 \\
\hline $\begin{array}{l}\text { S28d. Working under the sun for a long } \\
\text { time throughout life increases the risk of } \\
\text { skin cancer. }\end{array}$ & 207 & 81 & 39.13 & 88 & 42.51 & 33 & 15.94 & 5 & 2.42 & & \\
\hline $\begin{array}{l}\text { S28e. Having a family member with skin } \\
\text { cancer increases the risk of developing } \\
\text { skin cancer. }\end{array}$ & 209 & 66 & 31.58 & 86 & 41.15 & 47 & 22.49 & 7 & 3.35 & 3 & 1.44 \\
\hline $\begin{array}{l}\text { S29. Sunbathing for only a week or two } \\
\text { in a year increases the risk of developing } \\
\text { skin cancer. }\end{array}$ & 215 & 24 & 11.16 & 23 & 10.70 & 121 & 56.28 & 39 & 18.14 & 8 & 3.72 \\
\hline S30. Solarium is a healthy way to tan. & 214 & 6 & 2.80 & 14 & 6.54 & 66 & 30.84 & 79 & 36.92 & 49 & 22.90 \\
\hline $\begin{array}{l}\text { S31. One can tan in the sun without an } \\
\text { adverse effect when sunscreen is used. }\end{array}$ & 213 & 13 & 6.10 & 81 & 38.03 & 46 & 21.60 & 64 & 30.05 & 9 & 4.23 \\
\hline $\begin{array}{l}\text { S32. Tanning protects against the } \\
\text { harmful effects of sunlight. }\end{array}$ & 213 & 5 & 2.35 & 33 & 15.49 & 76 & 35.68 & 75 & 35.21 & 24 & 11.27 \\
\hline $\begin{array}{l}\text { S33. Tanning in the solarium during } \\
\text { winter prevents the harmful effects of } \\
\text { the sun in summer. }\end{array}$ & 214 & 4 & 1.87 & 12 & 5.61 & 94 & 43.93 & 68 & 31.78 & 36 & 16.82 \\
\hline $\begin{array}{l}\text { S34. Gradual/slow tanning prevents the } \\
\text { harmful effects of the sun. }\end{array}$ & 213 & 19 & 8.92 & 72 & 33.80 & 83 & 38.97 & 32 & 15.02 & 7 & 3.29 \\
\hline S35. Tanning is a sign of sun damage. & 213 & 18 & 8.45 & 61 & 28.64 & 90 & 42.25 & 36 & 16.90 & 8 & 3.76 \\
\hline
\end{tabular}




\begin{tabular}{|l|l|l|l|l|l|l|l|l|l|l|l|}
\hline $\begin{array}{l}\text { S36. Having only two-three sunburns } \\
\text { throughout life does not increase the } \\
\text { risk of skin diseases. }\end{array}$ & 214 & 9 & 4.21 & 45 & 21.03 & 100 & 46.73 & 41 & 19.16 & 19 & 8.88 \\
\hline $\begin{array}{l}\text { S37. Ultraviolet rays in solarium are } \\
\text { healthier than ultraviolet rays from the } \\
\text { sun. }\end{array}$ & 214 & 2 & 0.93 & 15 & 7.01 & 85 & 39.72 & 62 & 28.97 & 50 & 23.36 \\
\hline
\end{tabular}

Those who used sunscreens started using them at the age of $16.61 \pm 7.86$ on average. Most of the participants ( $\mathrm{n}=114,52.53 \%$ ) used sunscreen on face daily whereas $38.71 \%$ did not use sunscreen daily in a regular manner. When they sunbathed (i.e. at the beach), however, a great majority of the participants $(80.18 \%$ and $71.43 \%$, respectively) did apply sunscreen on the face and upper extremities. The majority of those who used sunscreens (65.53\%) applied them half an hour before sun exposure. Brand and high SPF were the most frequently considered aspects ( $45.19 \%$ and $46.15 \%$, respectively) when buying sunscreens. A great majority of the participants were aware that the UV radiation was responsible for the harmful effects of the sun (97.44\%) and found it necessary to protect from the sun (88.94\%) (Table 3). The Internet was found to be the most common source of information about the harmful effects of the sun (52.17\%), followed by television (25.60\%).

A comparison of subgroups of participants based on gender, position, and area of study indicated some differences in practices related to sun exposure and sun protection (Table 4). No significant difference was found between males and females regarding the duration of daily sun exposure in summer ( $p=0.113)$, but females had a higher rate of sunscreen use ( $p=0.014)$, a lower rate of sunburn $(p=0.045)$, and used sunscreen with higher SPF ( $p=0.001)$. Students had longer daily sun exposure during summer $(p<0.001)$ and used lower SPF sunscreens or were less aware of the sunscreen SPF they used ( $p=0.002)$ compared with faculty members. Students considered the price first when buying sunscreens while faculty members paid attention to the brand more often $(p=0.006)$. Television and the Internet were the sources of information about sun exposure and protection more commonly for students than they were for faculty members who got information at school more often than students $(p<0.001)$. Students and faculty members in non-medical departments had higher daily sun exposure during summer $(p<0.001)$. Formal education at school was the source of information about sun exposure and protection more commonly for those in medical departments $(p=0.031)$.

The participants' responses to various statements regarding solarium use, sun exposure, sun protection, sunscreen use, and skin cancer were given in Table 5. A graphical presentation of the participant responses was also given in Figure 1. Subgroups were also analyzed and compared in terms of their responses to the statements about the effects of ultraviolet exposure from the sun or at the solarium and the methods of protection (Table 6). 
Table 6. Comparison of responses from various subgroups of participants to the statements about sun exposure, sun protection, sunscreen use, etc. Only the statements with significant differences between the groups' responses were given.

\begin{tabular}{|c|c|c|c|c|}
\hline Subgroups & Stater & & More correctly responding group & $p$-value ${ }^{a}$ \\
\hline \multirow{4}{*}{ Gender } & S21 & True & Male & $<0.001$ \\
\hline & S27 & True & Female & 0.006 \\
\hline & S28a & True & Female & 0.017 \\
\hline & S28e & True & Female & 0.042 \\
\hline \multirow{19}{*}{ Position } & S11a & False & Faculty member & $<0.001$ \\
\hline & S11b & True & Faculty member & 0.001 \\
\hline & S18 & False & Faculty member & 0.048 \\
\hline & S19 & True & Faculty member & 0.045 \\
\hline & S22 & True & Faculty member & $<0.001$ \\
\hline & S23 & True & Faculty member & 0.002 \\
\hline & S24 & True & Faculty member & $<0.001$ \\
\hline & S26 & True & Faculty member & $<0.001$ \\
\hline & S27 & True & Faculty member & $<0.001$ \\
\hline & S28a & True & Faculty member & $<0.001$ \\
\hline & S28b & True & Faculty member & $<0.001$ \\
\hline & S28c & True & Faculty member & $<0.001$ \\
\hline & S28d & True & Faculty member & $<0.001$ \\
\hline & S28e & True & Faculty member & $<0.001$ \\
\hline & S30 & True & Faculty member & $<0.001$ \\
\hline & S32 & True & Faculty member & $<0.001$ \\
\hline & S33 & True & Faculty member & $<0.001$ \\
\hline & S36 & True & Faculty member & 0.012 \\
\hline & S37 & True & Faculty member & 0.003 \\
\hline \multirow{14}{*}{ Area of study } & S11a & False & Medical & 0.008 \\
\hline & S11b & True & Medical & 0.008 \\
\hline & S18 & False & Medical & 0.013 \\
\hline & S24 & True & Medical & 0.001 \\
\hline & S26 & True & Medical & 0.035 \\
\hline & S27 & True & Medical & $<0.001$ \\
\hline & S28b & True & Medical & 0.001 \\
\hline & S28d & True & Medical & $<0.001$ \\
\hline & S28e & True & Medical & $<0.001$ \\
\hline & S30 & False & Medical & 0.002 \\
\hline & S31 & False & Medical & 0.003 \\
\hline & S32 & False & Medical & 0.012 \\
\hline & S33 & False & Medical & $<0.001$ \\
\hline & S37 & False & Medical & 0.016 \\
\hline
\end{tabular}

aMann-Whitney U test with numerically ranked responses (strongly agree $=1$, agree $=2$, not sure $=3$, disagree $=4$, strongly disagree $=5$ ). 


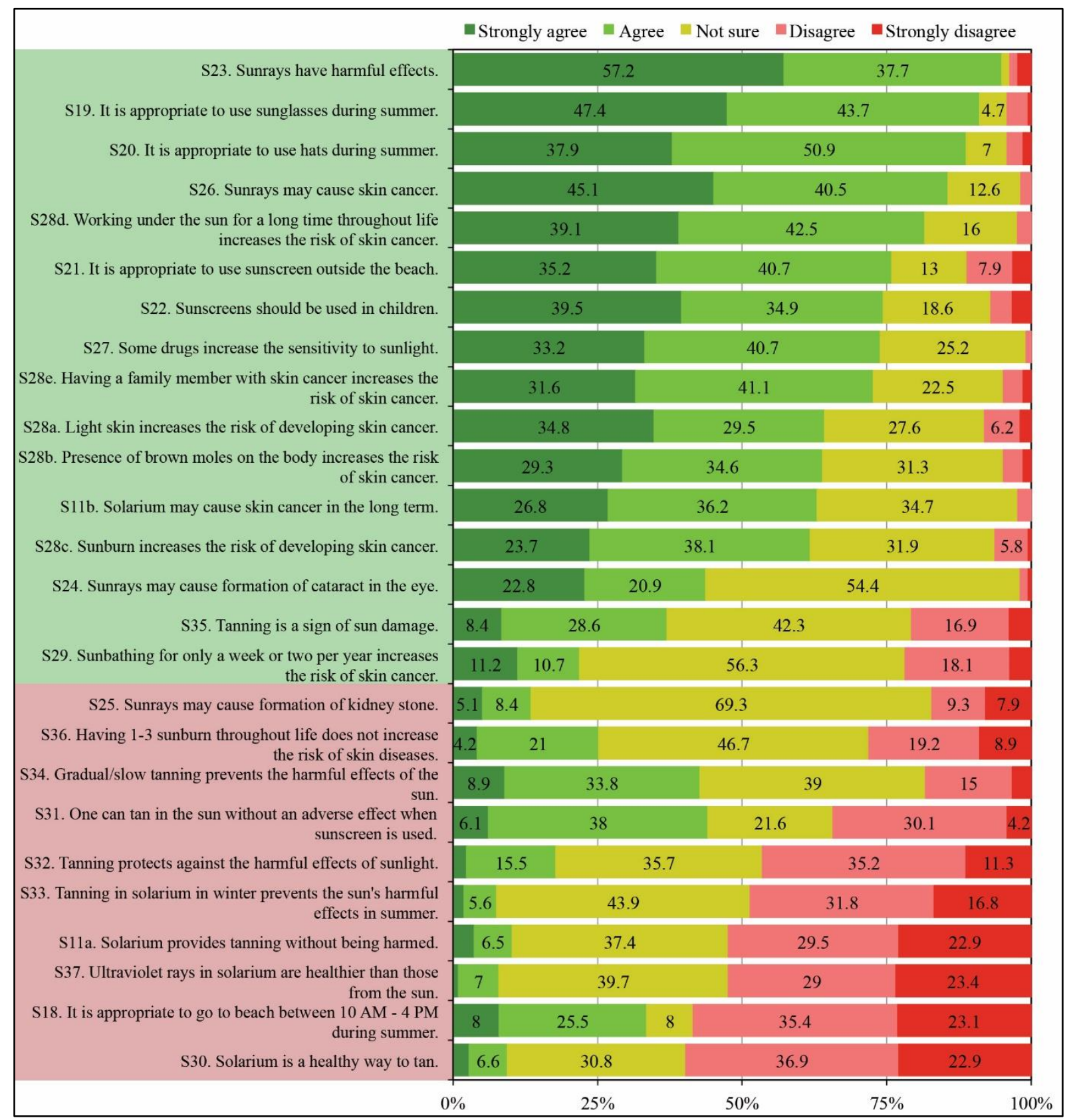

Figure 1. Stacked-bar graph showing the participants' opinions regarding sun exposure, sun protection, sunscreen use, and skin cancer. The statements were stratified as "True" (statements on y-axis were shaded in green) and "False" (statements on x-axis were shaded in red), and based on the percentages for consolidated response groups (Strongly agree \& Agree, greens; Not sure, yellow; Disagree \& Strongly disagree, reds). 


\section{Discussion}

Effectiveness of the sunscreens applied onto the skin depends on the SPF and appropriate usage of the product, both of which are significantly influenced by the knowledge and awareness of the public. ${ }^{11,12,18}$ However, studies have indicated that sun exposure behavior was difficult to change, and non-adherence to medical advice was common even in the face of skin cancer risks. ${ }^{19,20}$ It is, therefore, necessary to implement public awareness programs at the right time, to the right audience, with the right message, and through the right channels. This study investigated the level of knowledge and awareness about UV protection practices among the students of medicine or their educators and compared them to those from non-medical areas of study. Although students and faculty members from medical areas were generally found to have a higher level of knowledge about the subject matter, there was still room for improvement.

The rate of sunscreen use among university students and faculty members was found to be quite high (92.41\% and $97.22 \%)$, especially compared to those reported in previous studies on high school students (41.8\%) and their teachers $(81.9 \%)$ or other undergraduate populations $(63.5 \%)$ in Turkey as well as other medical students in several other countries (range from 52\% to 86\%).17,21,22 The higher rate of sunscreen use in this study might be attributed to the differences in the target populations. Female participants were found to be more likely to use sunscreen, less likely to have a sunburn, and to use sunscreens with higher SPF compared to their male counterparts. A previous study similarly found a significantly higher rate of sunscreen use among female college students compared to males (73.3\% vs. 52.5\%). ${ }^{21}$ This trend is in parallel with more common sunscreen usage among females in previous studies and reviews covering diverse populations. ${ }^{23-27}$ However, no significant differences were found between males and females regarding their responses to the majority of the statements about sun exposure and protection, sunscreen use, and other health issues related to tanning practices. This suggests that the lack of knowledge is not likely to be the reason for a lower rate of sunscreen use or a higher rate of sunburns among males. Congruently, cosmetic reasons were reported in a previous study to be the main behavioral motivation rather than health concerns or skin cancer risk. ${ }^{23}$ Although a low rate of sunscreen use might be associated with a higher rate of sunburns, we did not find a relationship between the two, which might be due to the fact that the number of participants who did not use sunscreens was very low.

Students and faculty members were found to have similar rates of sunscreen use and sunburn. Interestingly, a significantly higher number of students were found to consider price first when buying sun protection products, which contrasted the faculty members who more often indicated paying attention to brand name first. In a similar study, high school students were reported to considered price as a criteria in the selection of sunscreen more often than their teachers did. ${ }^{17}$ This is likely due to the financial differences between the two groups. In addition, the significantly higher unawareness among students about the SPF of the sunscreen product they used might be a manifestation of their price-focused attitude. Longer duration of daily sun 
exposure of students might be attributed to the lifestyle differences between younger and older groups of participants (see the age difference in Table 1). Television and the Internet were more commonly the source of information about the issues related to sun protection for students compared to faculty members, which might also be attributed to age and lifestyle differences between the two groups. Previous studies on college students also reported that the internet and television were primary sources of information about sun protection. ${ }^{23,24,26}$ Therefore, awareness campaigns targeting such (i.e., younger) audiences should take into consideration the alternative media outlets fitting their age and lifestyle to reach them more effectively. ${ }^{28}$

Lower daily sun exposure among the students and faculty members of medical departments might be due to a more demanding study and work schedule in medical fields. Formal education at school was more commonly the source of information about sun exposure and protection for the participants in medical departments as it was part of their subject of study and profession. Family was not found to be a significant source of information for the participants of our study (3.86\%) although parents and family were indicated to be a common source of knowledge about sun protection behavior in previous studies. ${ }^{26,29}$ The differences might be due to the variations in the preferences of the populations targeted in other studies.

The participants were asked to respond to various statements regarding various aspects of UV exposure and protection. These statements covered the subjects related to the use and knowledge of solarium, tanning, harmful effects of sunrays, risk factors for skin cancer, protective measures in summer, and sunscreen use. Some of these statements were in parallel with clinical knowledge (true) while others contradicted the clinical knowledge and reflected some common misconceptions (false). It was found that six out of 16 correct statements were identified by three-quarters or more of the respondents; 13 out of 16 correct statements were identified by more than half of the respondents (bars in shades of green in Figure 1). Six out of ten false statements were identified by about half of the respondents (bars in shades of red in Figure 1). Most of the participants failed to set opinions on three of the correct statements $(S 23, S 29, S 35)$ and two of the false statements (S25, S36) (yellow bars in Figure 1). Some of these statements were related to sun-exposure-related risk factors for skin disease or cancer, which indicated a lack of knowledge about these issues. Almost half of the respondents identified two false statements as correct (S31, S34). These statements were related to the common misconceptions that one could tan in the sun without an adverse effect when sunscreen was used (S31) and that gradual/slow tanning prevented the harmful effects of the sun (S34). ${ }^{22}$

Significant differences between the response patterns of males and females existed in only four statements (S21, S27, S28ae); female participants more correctly responded to three of these statements. Significant differences between the response patterns of students and faculty members existed in most of the statements; faculty members more correctly responded in all such cases. The participants from medical and non-medical 
departments also exhibited significant differences in terms of their ability to respond correctly; those from medical fields responded more correctly in all such cases.

Although the majority of the responses from the participants in medical fields were in parallel with the clinical knowledge, there were instances where a significant portion of them responded incorrectly. Nine out of 16 correct statements were identified by three-quarters or more of the respondents ( 4 items for non-medical participants); 14 out of 16 correct statements were identified by more than half of the respondents (11 items for non-medical participants). Six out of ten false statements were identified by about half of the respondents (2 items for non-medical participants). Participants from medical fields failed to set opinions on two of the correct statements and one of the false statements (this was the case in 5 correct and 5 false statements for non-medical participants). Three statements, in particular, ("S18. It is appropriate to go to beach between 10 AM - 4 PM during summer", "S31. One can tan in the sun without an adverse effect when sunscreen is used", and "S34. Gradual/slow tanning prevents the harmful effects of the sun"), were erroneously taken as correct statements by a significant portion of the participants, even so among those from medical backgrounds. These findings indicate a need for educating students of medicine about skin cancer risks and preventive measures as emphasized by a recent comprehensive review of skin-cancer-related knowledge, attitudes, and practices among medical students. ${ }^{22}$

This study has some limitations regarding the data collection tool. Although items and elements from other studies were adapted and used in this study, the fact that the questionnaire used in this study was not a validated scale to assess the participants' behavior or knowledge regarding the hazards of sun exposure, protection from such hazards, and related subjects inhibited us from going beyond making a qualitative analysis and reaching some general conclusions. ${ }^{13,17,30}$ Another significant limitation of this study was the sample size and restriction of sampling to a single institution of higher education. Although the sample was believed to reflect the average among the institutions of higher education in Turkey in terms of behaviors and practices, this was not a confirmed assumption. Further studies with more comprehensive and well-managed data collection tools including a larger sample from a more diverse set of institutions are warranted to determine the knowledge and behaviors of the target population regarding the hazards of sun exposure and sun protection.

In conclusion, this study investigated the level of knowledge and awareness among the students of medicine and their educators about UV protection practices and compared them to those from non-medical areas of study. The results indicated that although students and faculty members of medical areas generally had higher level of knowledge about the issues surrounding sun exposure, sun protection, sunscreen use, and other tanning practices in comparison with those from non-medical backgrounds, there is still a significant knowledge deficit about the severity of the risks associated with sun exposure and some room for improvement 
even among the students and faculty members of medical schools. The methods and media channels that would be used to increase public awareness should be adapted to the target audiences regarding the demographic characteristics.

\section{References}

1. Guy GP Jr, Machlin SR, Ekwueme DU, Yabroff KR. Prevalence and costs of skin cancer treatment in the U.S., 2002-2006 and 2007-2011. Am J Prev Med 2015;48(2):183-7.

2. Craythorne E, Al-Niami F. Skin cancer. Medicine 2017;45(7):431-4.

3. Van Dijk A, Den Outer PN, Slaper H. Climate and Ozone change Effects on Ultraviolet radiation and Risks (COEUR). Using and validating earth observations. RIVM Report 61000 2001/2008. Bilthoven, The Netherlands: The National Institute for Public Health and the Environment in the Netherlands (RIVM); 2008.

4. Holick MF. Biological effects of sunlight, ultraviolet radiation, visible light, infrared radiation and vitamin D for health. Anticancer Res 2016;36(3):1345-56.

5. Mitsis DK, Groman A, Beaupin LM, Salerno KE, Francescutti V, Skitzki JJ, et al. Trends in demographics, incidence, and survival in children, adolescents and young adults (AYA) with melanoma: A Surveillance, Epidemiology and End Results (SEER) population-based analysis. J Clin Oncol 2015;33(Suppl 15):9058.

6. Lozano R, Naghavi M, Foreman K, Lim S, Shibuya K, Aboyans V, et al. Global and regional mortality from 235 causes of death for 20 age groups in 1990 and 2010: a systematic analysis for the Global Burden of Disease Study 2010. Lancet 2012;380(9859):2095-128.

7. Gordon R. Skin cancer: an overview of epidemiology and risk factors. Semin Oncol Nurs 2013;29:1609.

8. Gallagher RP, Lee TK, Bajdik CD, Borugian M. Ultraviolet radiation. Chronic Dis Can 2010;29:51-68.

9. Arnold M, de Vries E, Whiteman DC, Jemal A, Bray F, Parkin DM, et al. Global burden of cutaneous melanoma attributable to ultraviolet radiation in 2012. Int J Cancer 2018;143(6):1305-14.

10. Narayanan DL, Saladi RN, Fox JL. Ultraviolet radiation and skin cancer. International J Dermatol 2010;49(9):978-86.

11. Lademann J, Schanzer S, Richter H, Pelchrzim RV, Zastrow L, Golz K, et al. Sunscreen application at the beach. J Cosmet Dermatol 2004;3:62-8.

12. Reinau D, Osterwalder U, Stockfleth E, Surber C. The meaning and implication of sun protection factor. Br J Dermatol 2015;173(5):1345-6.

13. Glanz K, Yaroch AL, Dancel M, Saraiya M, Crane LA, Buller DB, et al. Measures of sun exposure and sun protection practices for behavioral and epidemiologic research. Arch Dermatol 2008;144(2):217-22. 
14. Cokkinides V, Weinstock M, Glanz K, Albano J, Ward E, Thun M. Trends in sunburns, sun protection practices, and attitudes toward sun exposure protection and tanning among US adolescents, 19982004. Pediatrics 2006;118:853-64.

15. Emmons KM, Geller AC, Viswanath V, Rutsch L, Zwirn J, Gorham S, et al. The SunWise Policy intervention for school-based sun protection: a pilot study. J Sch Nurs 2008;24:215-21.

16. Barrow MM. Approaching skin cancer education with a clear message: "Be safe. Be SunAWARE." J Dermatol Nurs 2010;2:209-13.

17. Şenel E, Süslü I. Knowledge, attitudes, and behaviors regarding sun protection, effects of the sun, and skin cancer among Turkish high school students and teachers. Dermatol Sin 2015;33(4):187-90.

18. Couteau C, Diarra H, Coiffard L. Effect of the product type, of the amount of applied sunscreen product and the level of protection in the UVB range on the level of protection achieved in the UVA range. Int J Pharm 2016;500(1-2):210-6.

19. Rodrigues A, Sniehotta FF, Araujo-Soares V. Are interventions to promote sun-protective behaviors in recreational and tourist settings effective? A systematic review with meta-analysis and moderator analysis. Ann Behav Med 2013;45:224e38.

20. Sarkany R. Sun protection strategies. Medicine 2017;45(7):444-7.

21. Baykal Selcuk L, Aksu Arica D, Ates E, Yayli S, Bahadir S. Sun-protective behaviours of Turkish young adults. Photodermatol Photoimmunol Photomed 2019;00:1-9. (doi: 10.1111/phpp.12450)

22. Nahar VK, Wilkerson AH, Ghafari G, Martin B, Black WH, Boyas JF, et al. Skin cancer knowledge, attitudes, beliefs, and prevention practices among medical students: A systematic search and literature review. Int J Women's Dermatol 2018;4(3):139-49.

23. Buchanan Lunsford N, Berktold J, Holman DM, Stein K, Prempeh A, Yerkes A. Skin cancer knowledge, awareness, beliefs and preventive behaviors among black and hispanic men and women. Prev Med Rep 2018;12:203-9.

24. Lovejoy J, Riffe D, Lovejoy TI. An examination of direct and indirect effects of exposure and attention to health media on intentions to avoid unprotected sun exposure. Health Commun 2015;30(3):26170 .

25. Dupont L, Pereira DN. Sun exposure and sun protection habits in high school students from a city south of the country. An Bras Dermatol 2012;87:90e5.

26. Bruce A, Theeke L, Mallow J. A state of the science on influential factors related to sun protective behaviors to prevent skin cancer in adults. Int J Nurs Sci 2017;4(3):225-35.

27. Calderón TA, Bleakley A, Jordan AB, Lazovich D, Glanz K. Correlates of sun protection behaviors in racially and ethnically diverse U.S. adults. Prev Med Rep 2019;13:346-53.

28. Falzone AE, Brindis CD, Chren MM, Junn A, Pagoto S, Wehner M, et al. Teens, tweets, and tanning beds: rethinking the use of social media for skin cancer prevention. Am J Prev Med 2017;53(3):S86-S94. 
29. Hedges T, Scriven A. Young park users 'attitudes and behaviour to sun protection. Glob Health Promot 2010;17(4):24e31.

30. Glanz K, Schoenfeld ER, Steffen A. A randomized trial of tailored skin cancer prevention messages for adults: Project SCAPE. Am J Public Health 2010;100(4):735-41. 